\title{
Enhanced Behavioral Response to Serotonin-Related Agonists in Postweaning Protein Malnourished Mice
}

\author{
Shoko Sato, ${ }^{a}$ Osamu Nakagawasai, ${ }^{* b}$ Takafumi Hayashi, ${ }^{a}$ Atsuko Oikawa,${ }^{a}$ Fukie Yaoita, ${ }^{b}$ \\ Koichi Tan-no, ${ }^{b}$ Takeshi Tadano, ${ }^{b}$ and Tsuneyoshi Suzuki ${ }^{a}$ \\ ${ }^{a}$ Department of Pharmaceutical Sciences, Tohoku Pharmaceutical University; and ${ }^{b}$ Department of Pharmacology, \\ Tohoku Pharmaceutical University; 4-4-1 Komatsushima, Aoba-ku, Sendai 981-8558, Japan.
}

Received February 24, 2012; accepted July 7, 2012; advance publication released online July 25, 2012

We investigated whether postweaning protein malnutrition (PM) affects serotonergic systems. Mice were fed a PM diet or normal protein (control) diet from weaning (21 d of age). Twenty days later, we tested for behavioral effects of the selective serotonin $(5-\mathrm{HT})_{1 \mathrm{~A}}$ receptor agonist 8 -hydroxy- $N, N$-dipropyl-2-aminoteralin (8-OH-DPAT) and the 5-HT releaser $d$-fenfluramine. The number of head weaving responses induced by 8-OH-DPAT or $d$-fenfluramine in the PM mice was significantly increased compared with the control diet group. The effects of 8-OH-DPAT and $d$-fenfluramine were blocked by pretreatment with the selective $5-\mathrm{HT}_{1 \mathrm{~A}}$ receptor antagonist WAY-100635 $(0.01 \mathrm{mg} / \mathrm{kg})$. However, postpubertal $(56 \mathrm{~d}$ of age) mice fed with the PM diet did not show an enhancement of the 8-OH-DPAT-induced head weaving response. These results indicate the occurence of a supersensitivity of postsynaptic 5-HT $1 \mathrm{~A}$ receptor in the postweaning PM group. Moreover, they highlight the postweaning stage as a vulnerable period to malnutrition-induced alterations in central serotonergic systems. mouse

Key words protein malnutrition; serotonin $_{1 \mathrm{~A}}$; serotonin syndrome; head weaving; post-weaning period;

Serotonin (5-HT) is involved in the control of numerous physiological functions (e.g. food intake, thermoregulation, sleep patterns and nociception) ${ }^{1)}$ as well as in some psychiatric disorders such as anxiety and depression. ${ }^{2)}$ These multiple actions are mediated through activation of at least 15 different families of serotonergic receptors. ${ }^{3)}$ The $5-\mathrm{HT}_{1 \mathrm{~A}}$ receptor is one of the best described receptor subtypes and may be present on presynaptic as well as postsynaptic neurons. ${ }^{4)} 5-\mathrm{HT}_{1 \mathrm{~A}}$ agonists have been successfully used in the treatment of anxiety disorders in human. ${ }^{5)}$ However, excessive stimulation of postsynaptic $5-\mathrm{HT}_{1 \mathrm{~A}}$ receptor can lead to the 5-HT syndrome, a toxic condition displaying multiple clinical features. ${ }^{6)}$ In rodents, the administration of high doses of 5- $\mathrm{HT}_{1 \mathrm{~A}}$ agonist, e.g. 8-hydroxy- $N, N$-dipropyl-2-aminotetralin (8-OH-DPAT), also elicits a 5-HT syndrome with typical major behavioral components such as flat body posture, hind limb abduction, forepaw treading, and head weaving. ${ }^{7)}$

5-HT concentrations are strongly influenced by undernourishment. ${ }^{8)}$ 5-HT is synthesized from the amino acid precursor tryptophan and therefore is dependent on the latter's bioavailability. Brain levels of both are believed to increase as a result of metabolic adaptation to protein deficiency, which induces a decrease in the molar ratio of bound tryptophan to albumin. ${ }^{9)}$ However, some studies have reported either a decrease or no changes in brain serotonin levels following protein malnutrition (PM). ${ }^{10-12)}$ Several experimental studies have focused on the consequences of prenatal (i.e., gestation period) and early postnatal (i.e., lactation period) malnutrition. PM during these developmental stages causes various atypical behaviors in rats, such as reduced anxiety, ${ }^{13)}$ decreased social interaction, ${ }^{14)}$ increased depressive behavior, ${ }^{15)}$ prepulse inhibition deficit ${ }^{16}$ and impairment of memory-related behavior. ${ }^{17)}$ Moreover, a reduction in 5- $\mathrm{HT}_{1 \mathrm{~A}}$ receptor levels and 5-HT uptake sites was reported in the hippocampus of prenatal PM rats. ${ }^{12)}$ Since the

The authors declare no conflict of interest.
$5-\mathrm{HT}_{1 \mathrm{~A}}$ receptor is considered to be a key receptor via which 5-HT participates in hippocampal dependent learning and memory functions, ${ }^{18)}$ PM may impact on cognitive performances as well. Thus, it is considered that the developmental period extending from gestation to weaning is critical with regards to PM. However, it has become apparent that brain development continues through adolescence. ${ }^{19)}$ The age range for which the brain is vulnerable to the effects of malnutrition is potentially much greater than previously suspected but the threshold for malnutrition necessary to produce the behavioral alterations is unknown. ${ }^{20}$ Previously, we have reported that mice fed on the PM diet for $20 \mathrm{~d}$ during the prepubertal period (postnatal days 20-21; early postweaning) showed memory deficits and a decrease in choline acetyltransferase (ChAT) protein in the hippocampus. ${ }^{21)}$ Changes in the 5-HT system may underlie some of the observed morphological and cognitive changes previously reported. However, the effect of postweaning PM on serotonergic systems remains unclear.

The present study was designed to clarify the possible changes in serotonergic systems in postweaning PM mice. We investigated whether postweaning $\mathrm{PM}$ affects a $5-\mathrm{HT}_{1 \mathrm{~A}}$ related behavior namely the head weaving response induced by the selective $5-\mathrm{HT}_{1 \mathrm{~A}}$ receptor agonist $8-\mathrm{OH}-\mathrm{DPAT}$. Likewise, we examined the effects of PM on presynaptic serotonergic functions using the head weaving response induced by the 5-HT releaser $d$-fenfluramine.

\section{MATERIALS AND METHODS}

Animal Treatment Male ddY mice (Japan SLC, Hamamatsu, Japan) weighing 10-12g (postnatal day 21: prepubertal) or $38-42 \mathrm{~g}$ (postnatal day 56: postpubertal) at the beginning of the experiment were used in this study. The animals were weaned on postnatal day 20 by the supplier, housed ten per cage, and maintained under the conditions of constant temperature $\left(23 \pm 1^{\circ} \mathrm{C}\right)$ and humidity $(55 \pm 5 \%)$ on a $12 \mathrm{~h} / 12 \mathrm{~h}$ light-dark 


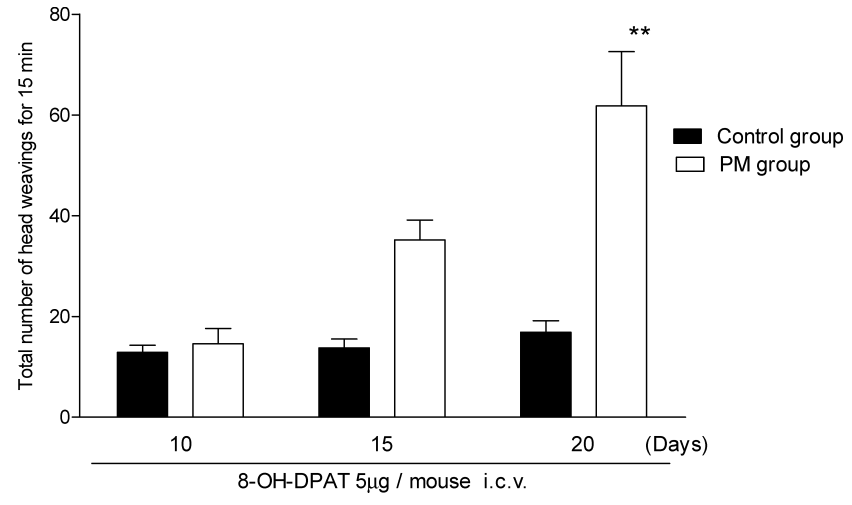

Fig. 1. Changes in 8-OH-DPAT-Induced Head Weaving Response in Mice on the 10th, 15th and 20th Day of PM Diet Feeding

Head weavings were counted for $15 \mathrm{~min}$ after the administration of 8-OH-DPAT $(5 \mu \mathrm{g} /$ mouse, i.c.v.). Each column shows the total number of head weavings. Vertical bars represent standard errors of means (S.E.M.). $N=10$ per group. $* * p<0.0$ significant difference between control group and PM group (two-way ANOVA; Bonferroni post hoc test).

cycle (light from 9 to $21 \mathrm{~h}$; dark from 21 to $9 \mathrm{~h}$ ). The mice had free access to food and water throughout the experimental period. They were housed in plastic cages $(31 \times 21 \times 13 \mathrm{~cm})$ and divided into two different dietary groups for 20 experimental days: (1) the PM group was provided daily with a 5\% casein diet (powdered PM diet, Ajinomoto Co., Inc., Kawasaki, Japan) and (2) the control group was given a $20 \%$ casein standard protein diet (powdered standard diet, Ajinomoto Co., Inc.). The detailed composition of the diet has been previously reported. ${ }^{16)}$ All experiments were performed according to the Guide for Care and Use of Laboratory Animals at Tohoku Pharmaceutical University.

Drugs 8-OH-DPAT, dissolved in Ringer's solution, was administered intracerebroventricularly (i.c.v.). The technique employed herein for i.c.v. injection into mice was the same as that originally described by Brittain and Handley. ${ }^{22}$ Briefly, i.c.v. administration of 8-OH-DPAT was performed with a disposable $27-\mathrm{G}$ needle attached to a $50 \mu \mathrm{L}$ Hamilton microsyringe and inserted into the left lateral ventricle of unanesthetized mice. $d$-Fenfluramine, dissolved in saline, was administered intraperitoneally (i.p.). $N$-[2-[4-(2-Methoxyphenyl)-1piperazinyl]ethyl]- $N$-(2-pyridinyl) cyclohexane carboxamide maleate (WAY-100635), dissolved in saline, was administered $(0.01 \mathrm{mg} / \mathrm{kg}$, subcutaneously (s.c.)) $30 \mathrm{~min}$ before 8 -OH-DPAT or $d$-fenfluramine injection.

Behavioral Observation Each mouse was allowed to adapt for $1 \mathrm{~h}$ in an observation cage $(25 \times 18 \times 13 \mathrm{~cm})$ before drug or vehicle injection. The number of head weavings (slow, side to side head movements) induced by 8 -OH-DPAT (0.625-5 $\mu \mathrm{g} / \mathrm{mouse}$, i.c.v.) and $d$-fenfluramine $(5-10 \mathrm{mg} / \mathrm{kg}$, i.p.) was recorded during $15 \mathrm{~min}$ and $60 \mathrm{~min}$ after the injection, respectively.

Statistical Analysis Statistical analyses were performed with the computer software GraphPad Prism 5.01 (Abacus Concepts, Berkeley, CA, U.S.A.). Influences of PM on the head weaving response induced by $8-\mathrm{OH}-\mathrm{DPAT}$ or $d$-fenfluramine in prepubertal mice were determined using a two-way analysis of variance (ANOVA). The Bonferroni post hoc test was conducted when appropriate. The effect of the postpubertal PM diet on the 8-OH-DPAT-induced head weaving response was determined using an unpaired $t$-test. A difference

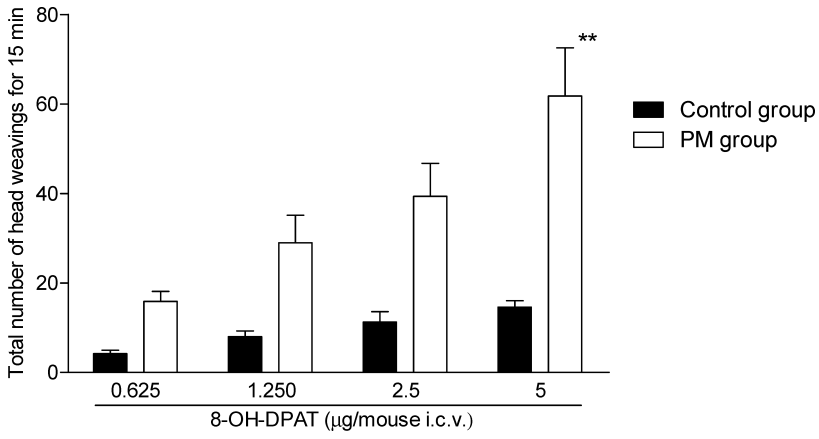

Fig. 2. 8-OH-DPAT-Induced Head Weaving Dose Response on the 20th Day of PM Diet Feeding

Head weavings were counted for $15 \mathrm{~min}$ after the administration of 8-OH-DPAT $(0.625-5 \mu \mathrm{g} /$ mouse, i.c.v.). Each column shows the total number of head weavings. Vertical bars represent S.E.M. $N=10$ per group. $* * p<0.01$ significant difference between control group and PM group (two-way ANOVA; Bonferroni post hoc test).

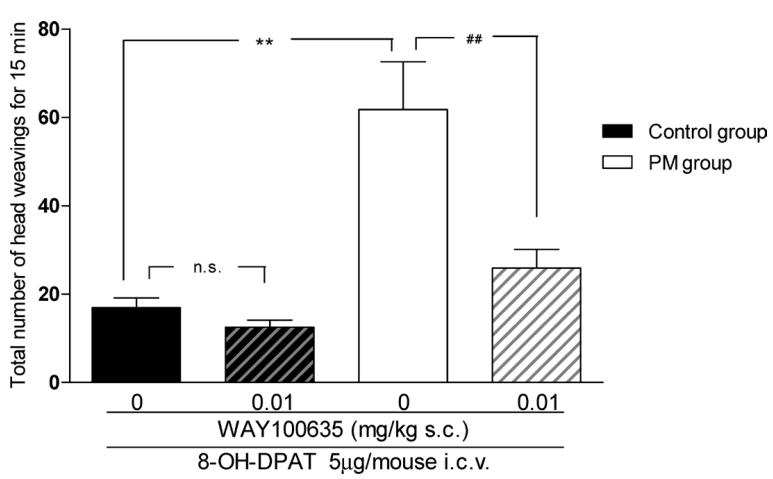

Fig. 3. Effects of WAY-100635 on the 8-OH-DPAT-Induced Head Weaving Response in PM Mice on the 20th Day of Diet Feeding

WAY-100635 was administrated $30 \mathrm{~min}$ before 8 -OH-DPAT ( $5 \mu \mathrm{g} / \mathrm{mouse}$, i.c.v.). $N=10$ per group. Each column shows the total number of head weavings. Vertical bars represent S.E.M. ${ }^{* *} p<0.01$ compared with vehicle treated control group, $\# p<0.01$ compared with vehicle treated PM group (two-way ANOVA; Bonferroni post hoc test).

of $p<0.05$ was considered significant. All results are given as mean \pm S.E.M.

\section{RESULTS}

Influence of PM on the Head Weaving Response Induced by 8-OH-DPAT in Prepubertal Mice The i.c.v. injection of the $5-\mathrm{HT}_{1 \mathrm{~A}}$ receptor agonist $8-\mathrm{OH}-\mathrm{DPAT}(5 \mu \mathrm{g} / \mathrm{mouse})$ caused an increase in the head weaving response that was significantly stronger in the 20-day PM diet-fed mice compared to the control mice (Fig. 1). No significant differences in the response between the two groups were observed 10 or $15 \mathrm{~d}$ after PM feeding.

A dose-dependent head weaving response in both control and PM mice was observed on the 20th day after the start of the experiment. However, a significantly greater increase in the head weaving response in PM mice compared to control mice was seen at the dose of $5 \mu \mathrm{g} /$ mouse (Fig. 2).

Effect of WAY-100635 on 8-OH-DPAT-Induced Head Weaving Response in Prepubertal PM mice The pretreatment of mice with the 5- $\mathrm{HT}_{1 \mathrm{~A}}$ receptor antagonist WAY-100635 $(0.01 \mathrm{mg} / \mathrm{kg}, \quad$ s.c. $)$ significantly decreased the 8-OH-DPAT-induced head weaving response in the 20-day 


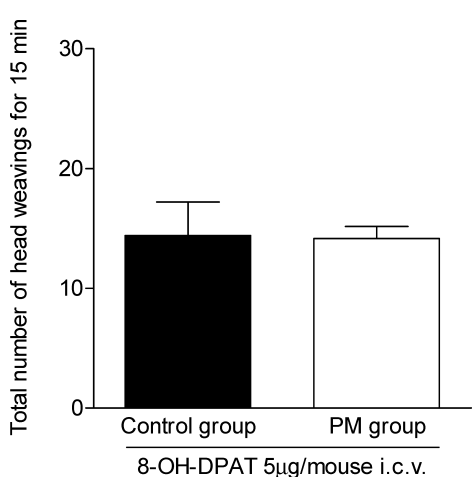

Fig. 4. 8-OH-DPAT-Induced Head Weaving Response on the 20th Day of PM Diet Feeding Starting from Postnatal Day 56

Each column shows the total number of head weavings counted for $15 \mathrm{~min}$ after the administration of 8 -OH-DPAT $(5 \mu \mathrm{g} /$ mouse, i.c.v. $)$. Vertical bars represent S.E.M. (unpaired $t$-test). $N=5$ per group.

PM diet-fed mice only (Fig. 3). The number of head weavings dropped to values observed for the control mice.

Influence of PM on the Head Weaving Response Induced by 8-OH-DPAT in Postpubertal mice Postnatal day 56 (postpubertal) mice were fed a PM or normal diet for $20 \mathrm{~d}$ before 8 -OH-DPAT administration ( $5 \mu \mathrm{g} /$ mouse). No differences in the induced head weaving response were found between control and PM mice (Fig. 4).

Influence of Prepubertal PM on the Head Weaving Response Induced by $\boldsymbol{d}$-Fenfluramine The injection of the 5 -HT releaser $d$-fenfluramine $(10 \mathrm{mg} / \mathrm{kg}$, i.p.) caused a significantly stronger enhancement of the head weaving response in prepubertal mice fed $20 \mathrm{~d}$ with the PM diet compared with the control diet (Fig. 5A). The pretreatment of mice with WAY-100635 $(0.01 \mathrm{mg} / \mathrm{kg}$, s.c. $)$ significantly decreased the $d$-fenfluramine-induced head weaving response in the PM diet-fed mice to control group level, as measured on the 20th experimental day (Fig. 5B). This dose of WAY-100635 did not inhibit the fenfluramine-induced head weaving response in control mice.

(A)

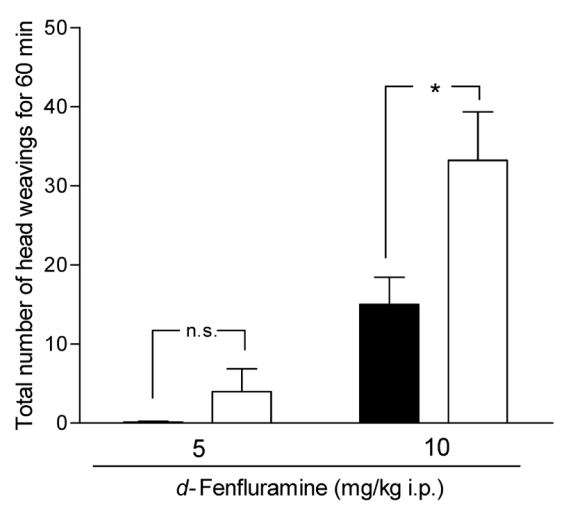

\section{DISCUSSION}

In rodents, a high dose of 8-OH-DPAT will induce a 5-HT behavioral syndrome that is characterized by head weaving, hindlimb abduction, forepaw treading and flat body posture. This syndrome is believed to be mediated by postsynaptic $5-\mathrm{HT}_{1 \mathrm{~A}}$ receptor since the behavioral effects are not reduced by the 5-HT depleter, $p$-chlorophenylalanine. ${ }^{7)}$ In the present study, we investigated whether postweaning PM affects $5-\mathrm{HT}_{1 \mathrm{~A}}$ receptor related behavior. As a result, the number of head weavings induced by 8-OH-DPAT was markedly enhanced in postweaning mice after $20 \mathrm{~d}$ on a PM diet (Figs. 1, 2). Moreover, the enhancement of the 8-OH-DPAT-induced head weaving response in PM mice was inhibited by pretreatment with a dose of the highly selective $5-\mathrm{HT}_{1 \mathrm{~A}}$ antagonist WAY-100635 that did not inhibit the 8-OH-DPAT-induced head weaving response in control mice (Fig. 3). These results suggest that PM in the postweaning mouse increases the responsitivity of $5-\mathrm{HT}_{1 \mathrm{~A}}$ postsynaptic receptor to agonist stimulation. In contrast, we observed that the administration of 5- $\mathrm{HT}_{2 \mathrm{~A} / 2 \mathrm{C}}$ receptor agonist $( \pm)$-1-(2,5-dimethoxy-4-iodophenyl)-2-aminopropane $\mathrm{HCl}[( \pm)-\mathrm{DOI} \mathrm{HCl}]$ did not cause any behavioral changes in prepubertal PM mice (data not shown). Therefore, these results suggest that the $5-\mathrm{HT}_{1 \mathrm{~A}}$ receptor may be vulnerable to the effect of postweaning PM.

Although the influence of early postnatal undernutrition on the serotonergic systems has been the subject of considerable biochemical research, ${ }^{23-25)}$ the data on brain serotonin content in early undernourishment is conflicting. While most studies have found an increase in serotonin concentration ${ }^{23-27)}$ others have reported a decrease or no change in undernourished rodents or humans. ${ }^{11,12,28,29)}$ In addition, previous studies have shown that PM causes a reduction in $5-\mathrm{HT}_{1 \mathrm{~A}}$ binding ${ }^{12)}$ and hyporeactivity to $5-\mathrm{HT}_{1 \mathrm{~A}}$ receptor agonists. ${ }^{30,31)}$ On the other hand, Laino et al. ${ }^{32)}$ found a PM-induced hyperreactivity to $5-\mathrm{HT}_{1 \mathrm{~A}}$ receptor agonists. Our results agree with the latter. Although the reasons for this disparity of results remain unclear, the type of nutritional deficiency (period, severity and the presence or absence of nutritional rehabilitation) may play a role. It remains to be determining the relationship between

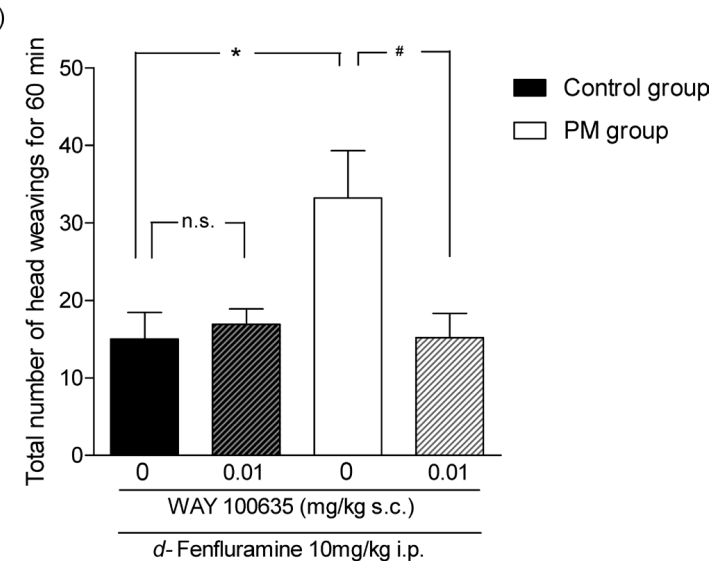

Fig. 5. Changes of $d$-Fenfluramine-Induced Head Weaving Response on the 20th Day of PM Diet Feeding

(A) Head weavings were counted for $60 \mathrm{~min}$ after the administration of $d$-fenfluramine $\left(5-10 \mathrm{mg} / \mathrm{kg}\right.$, i.p.). ${ }^{*} p<0.05$ significant difference between control group and PM group (two-way ANOVA; Bonferroni post hoc test). (B) The effects of WAY-100635 on $d$-fenfluramine-induced head weaving response on the 20 th day of diet feeding. ${ }^{*} p<0.05$ significant difference between control (vehicle treated) group and PM group (vehicle treated). ${ }^{\#}<<0.05$ significant difference between PM (vehicle treated) group and PM group (WAY-100635 treated). Each column shows the total number of head weavings for 60 min (two-way ANOVA; Bonferroni post hoc test). N=10 per group. Vertical bars represent S.E.M. 
the behavioral changes in our postweaning PM mice and the neurochemical and/or 5-HT $\mathrm{H}_{1 \mathrm{~A}}$ receptor binding examinations.

Recently, Bert et al. ${ }^{33)}$ reported a new transgenic mouse model with a prominent over-expression of the $5-\mathrm{HT}_{1 \mathrm{~A}}$ receptor in the outer cortical layers (I-III) and the dentate gyrus. In these animals, head weaving could be induced at a relatively low dose of 8-OH-DPAT whereas 5-HT levels and turnover were unaffected in serotonergic projection areas. ${ }^{33)}$ Although the brain region responsible for head weaving response has not been conclusively demonstrated, the transgenic mouse model indicate the relevance between head weaving response and these brain region. PM feeding has been reported to result in structural and neurochemical degeneration in hippocampus, ${ }^{34,35)}$ prefrontal, $^{36)}$ parietal $^{37,38)}$ and visual ${ }^{39)}$ cortices. However, there are few report similar nutritional deficiency protocol as ours. ${ }^{40)}$ Further studies are needed to clarify the brain region responsible for the enhancement of the $5-\mathrm{HT}_{1 \mathrm{~A}}$ agonist induced head weaving reseponse in our postweaning PM model.

Interestingly, in the present study we showed that the postpubertal stage is not as sensitive to PM as the postweaning stage with regards to developing supersensitivity to $5-\mathrm{HT}_{1 \mathrm{~A}}$ stimulation. Indeed, no increase in the number of head weavings induced by 8-OH-DPAT was observed between undernourished and control mice at the former stage (Fig. 4). This data may reflect differences in the plasticity between the developing and mature mouse brain. It is also consistent with our previous report on the induction in mice of behavioral effects such as alterations in cognitive function ${ }^{21)}$ and reduced anxiety behavior ${ }^{41)}$ by PM during the prepubertal but not postpubertal stage. Recently it has become apparent that brain development continues through adolescence and that prepubescence represents a period sensitive to nutritional deficits, ${ }^{42)}$ drug abuse ${ }^{43)}$ and isolation rearing. ${ }^{44)}$ In the rat, some brain structures, such as the hippocampus, are not even fully developed until as late as postnatal days 35-40.45) Majority $(85 \%)$ of the granule cells of the dentate gyrus are generated postnatally with the greatest cell proliferation between postnatal days 20-30, ${ }^{46)}$ and may continue to be generated well into adult life. ${ }^{47-49)}$ Similarly, neurotransmitter levels (noradrenaline, dopamine and 5-HT) continue to develop postnatally, reaching adult levels between $30-50 \mathrm{~d}$ of age. ${ }^{50)}$ This delays pattern of postnatal development may be due to the brain vulnerable to the effect of the postweaning PM. Moreover, during development, 5-HT is involved in processes of neuronal growth and differentiation, namely in neurogenesis ${ }^{51)}$ and synaptogenesis. ${ }^{52)}$ Lo Iacono and Gross ${ }^{53)}$ had demonstrated the third, fourth, and fifth postnatal weeks as a critical time for serotonin signaling in the maturation and/or refinement of brain circuits. The multiple actions of 5-HT during the developmental period may play a role in the vulnerability to prepubertal PM.

We next investigated whether the supersensitivity of postsynaptic $5-\mathrm{HT}_{1 \mathrm{~A}}$ receptors was evoked by presynaptic neuronal dysfunctions in PM mice. The head weaving response in rodents can also be induced by the administration of a 5-HT releaser. ${ }^{54)}$ Using microdialysis, it was shown that both physiological and precursor-induced release of 5-HT mainly occurs via exocytosis, probably from a small vesicular pool of de novo synthesized 5-HT. ${ }^{55}$ 5-HT releasers such as $d$-fenfluramine cause the release of cytoplasmic 5-HT into the synapse mainly through the 5-HT uptake carrier working in reverse. ${ }^{56)}$ We observed that the induction of the head weaving response by $d$-fenfluramine was increased in PM mice compared to control mice (Fig. 5A). The enhancement of the $d$-fenfluramine-induced head weaving response in PM mice was inhibited by pretreatment with a dose of the $5-\mathrm{HT}_{1 \mathrm{~A}}$ antagonist WAY-100635, which did not inhibit the $d$-fenfluramine-induced head weaving response in control mice (Fig. $5 B$ ). These results suggest that the supersensitivity of postsynaptic $5-\mathrm{HT}_{1 \mathrm{~A}}$ receptors in $\mathrm{PM}$ mice was not due to presynaptic serotonergic neuronal dysfunctions. In other words, the increase in the number of head weavings induced by $5-\mathrm{HT}_{1 \mathrm{~A}}$ agonist in postweanig PM mice may reflect an upregulation of postsynaptic $5-\mathrm{HT}_{1 \mathrm{~A}}$ receptors and/or downstream factor in it's signaling pathway.

We previously reported that postweaning PM causes an impairment in memory-related behaviors ${ }^{21)}$ and reduces the anxiety behavior. ${ }^{41)}$ There are indications that hippocampal $5-\mathrm{HT}_{1 \mathrm{~A}}$ receptors are crucial for the modulation of these behaviors. ${ }^{57,58)}$ Indeed, it has been demonstrated that hippocampal 5- $\mathrm{HT}_{1 \mathrm{~A}}$ receptor activation produces anxiolytic-like effects. ${ }^{59)}$ Moreover, the $5-\mathrm{HT}_{1 \mathrm{~A}}$ receptor is considered to be a key receptor via which 5-HT participates in hippocampal-dependent learning and memory functions. ${ }^{20)}$ We have not searched for potential changes in the distribution of $5-\mathrm{HT}_{1 \mathrm{~A}}$ receptors in this study. Further experiments are needed to clarify whether changes in $5-\mathrm{HT}_{1 \mathrm{~A}}$ receptor function are involved in the impairment of memory-related behavior and reduced anxiety behavior in postweaning PM mice.

In conclusion, the present results indicate an increased sensitivity of $5-\mathrm{HT}_{1 \mathrm{~A}}$ receptors in postweaning $\mathrm{PM}$ mice. Alteration in a $5-\mathrm{HT}_{1 \mathrm{~A}}$ related behavior was found in this specific age group. Our findings suggest that an adequate supply of protein is particularly important not only during the lactational/gestational period but also during the postweaning period.

Acknowledgements This study was supported in part by a Grant-in-Aid for Scientific Research (c) (KAKENHI 21610019) from the Japan Society for the Promotion of Science to T.T. and O.N., and Matching Fund Subsidy for Private Universities from the Ministry of Education, Culture, Sports, Science and Technology of Japan. The authors thank Ajinomoto Co., Inc., particularly Hitoshi Murakami and Kazunori Mawatari, for kindly providing the nutrient controlled diet.

\section{REFERENCES}

1) Shor-Posner G, Grinker JA, Marinescu C, Brown O, Leibowitz SF. Hypothalamic serotonin in the control of meal patterns and macronutrient selection. Brain Res. Bull., 17, 663-671 (1986).

2) Mann JJ. Role of the serotonergic system in the pathogenesis of major depression and suicidal behavior. Neuropsychopharmacology, 21 (Suppl.), 99S-105S (1999).

3) Whitaker-Azmitia PM. Serotonin and brain development: role in human developmental diseases. Brain Res. Bull., 56, 479-485 (2001).

4) Blier P, Lista A, De Montigny C. Differential properties of pre- and postsynaptic 5-hydroxytryptamine ${ }_{1 \mathrm{~A}}$ receptors in the dorsal raphe and hippocampus: I. Effect of spiperone. J. Pharmacol. Exp. Ther., 265, 7-15 (1993).

5) Sramek JJ, Zarotsky V, Cutler NR. Generalised anxiety disorder: 
treatment options. Drugs, 62, 1635-1648 (2002).

6) Sternbach H. The serotonin syndrome. Am. J. Psychiatry, 148, 705-713 (1991).

7) Yamada J, Sugimoto Y, Horisaka K. The behavioural effects of 8 -hydroxy-2-(di- $n$-propylamino)tetralin (8-OH-DPAT) in mice. Eur. J. Pharmacol., 154, 299-304 (1988).

8) Schaechter JD, Wurtman RJ. Serotonin release varies with brain tryptophan levels. Brain Res., 532, 203-210 (1990).

9) Resnick O, Morgane PJ. Ontogeny of the levels of serotonin in various parts of the brain in severely protein malnourished rats. Brain Res., 303, 163-170 (1984).

10) Chen JC, Turiak G, Galler J, Volicer L. Postnatal changes of brain monoamine levels in prenatally malnourished and control rats. Int. J. Dev. Neurosci., 15, 257-263 (1997).

11) Zhang L, Guadarrama L, Corona-Morales AA, Vega-Gonzalez A, Rocha L, Escobar A. Rats subjected to extended L-tryptophan restriction during early postnatal stage exhibit anxious-depressive features and structural changes. J. Neuropathol. Exp. Neurol., 65, 562-570 (2006).

12) Blatt GJ, Chen JC, Rosene DL, Volicer L, Galler JR. Prenatal protein malnutrition effects on the serotonergic system in the hippocampal formation: an immunocytochemical, ligand binding, and neurochemical study. Brain Res. Bull., 34, 507-518 (1994).

13) Almeida SS, Tonkiss J, Galler JR. Prenatal protein malnutrition affects exploratory behavior of female rats in the elevated plus-maze test. Physiol. Behav., 60, 675-680 (1996).

14) Almeida SS, De Araújo M. Postnatal protein malnutrition affects play behavior and other social interactions in juvenile rats. Physiol. Behav., 74, 45-51 (2001).

15) Jaiswal AK, Upadhyay SN, Satyan KS, Bhattacharya SK. Behavioural effects of prenatal and postnatal undernutrition in rats. Indian J. Exp. Biol., 34, 1216-1219 (1996).

16) Palmer AA, Printz DJ, Butler PD, Dulawa SC, Printz MP. Prenatal protein deprivation in rats induces changes in prepulse inhibition and NMDA receptor binding. Brain Res., 996, 193-201 (2004).

17) Fukuda MT, Françolin-Silva AL, Almeida SS. Early postnatal protein malnutrition affects learning and memory in the distal but not in the proximal cue version of the Morris water maze. Behav. Brain Res., 133, 271-277 (2002).

18) Carli M, Luschi R, Garofalo P, Samanin R, Samanin R. 8-OH-DPAT impairs spatial but not visual learning in a water maze by stimulating $5-\mathrm{HT}_{1 \mathrm{~A}}$ receptors in the hippocampus. Behav. Brain Res., 67, 67-74 (1995).

19) Benton D, ILSI Europe a.i.s.b.l. The influence of children's diet on their cognition and behavior. Eur. J. Nutr., 47 (Suppl 3.), 25-37 (2008).

20) Levitsky DA, Strupp BJ. Malnutrition and the brain: changing concepts, changing concerns. J. Nutr., 125 (Suppl.), 2212S-2220S (1995).

21) Nakagawasai $O$, Yamadera $F$, Sato $S$, Taniguchi R, Hiraga H, Arai Y, Murakami H, Mawatari K, Niijima F, Tan-No K, Tadano T. Alterations in cognitive function in prepubertal mice with protein malnutrition: relationship to changes in choline acetyltransferase. Behav. Brain Res., 167, 111-117 (2006).

22) Brittain RT, Handley SL. Temperature changes produced by the injection of catecholamines and 5-hydroxytryptamine into the cerebral ventricles of the conscious mouse. J. Physiol., 192, 805-813 (1967).

23) Chen JC, Tonkiss J, Galler JR, Volicer L. Prenatal protein malnutrition in rats enhances serotonin release from hippocampus. J. Nutr., 122, 2138-2143 (1992).

24) Hernández J, Manjarréz GG, Chagoya G. Newborn humans and rats malnourished in utero: free plasma L-tryptophan, neutral amino acids and brain serotonin synthesis. Brain Res., 488, 1-13 (1989).

25) Hisatomi K, Niiyama Y. Effects of postnatal undernutrition on the catecholamine and serotonin contents of suckling rat brain. J. Nutr.
Sci. Vitaminol. (Tokyo), 26, 279-292 (1980).

26) Sobotka TJ, Cook MP, Brodie RE. Neonatal malnutrition: neurochemical, hormonal and behavioral manifestations. Brain Res., 65, 443-457 (1974).

27) Fernstrom JD, Wurtman RJ. Brain serotonin content: increase following ingestion of carbohydrate diet. Science, 174, 1023-1025 (1971).

28) Ahmad G, Rahman MA. Effects of undernutrition and protein malnutrition on brain chemistry of rats. J. Nutr., 105, 1090-1103 (1975).

29) Schweiger U, Broocks A, Tuschl RJ, Pirke KM. Serotonin turnover in rat brain during semistarvation with high-protein and high-carbohydrate diets. J. Neural Transm., 77, 131-139 (1989).

30) Almeida SS, Tonkiss J, Galler JR. Malnutrition and reactivity to drugs acting in the central nervous system. Neurosci. Biobehav. Rev., 20, 389-402 (1996).

31) Hall RD, Leahy JP, Robertson WM. Hyposensitivity to serotonergic stimulation in protein malnourished rats. Physiol. Behav, 31, 187-195 (1983).

32) Laino $\mathrm{CH}$, Cordoba NE, Orsingher OA. Perinatally protein-deprived rats and reactivity to anxiolytic drugs in the plus-maze test: an animal model for screening antipanic agents? Pharmacol. Biochem. Behav., 46, 89-94 (1993).

33) Bert B, Fink H, Hörtnagl H, Veh RW, Davies B, Theuring F, Kusserow H. Mice over-expressing the 5-HT(1A) receptor in cortex and dentate gyrus display exaggerated locomotor and hypothermic response to 8-OH-DPAT. Behav. Brain Res., 167, 328-341 (2006).

34) Andrade JP, Lukoyanov NV, Paula-Barbosa MM. Chronic food restriction is associated with subtle dendritic alterations in granule cells of the rat hippocampal formation. Hippocampus, 12, 149-164 (2002).

35) Morgane PJ, Mokler DJ, Galler JR. Effects of prenatal protein malnutrition on the hippocampal formation. Neurosci. Biobehav. Rev., 26, 471-483 (2002).

36) Soto-Moyano R, Hernandez A, Perez H, Ruiz S, Diaz-Veliz G, Belmar J. Early malnutrition and changes in the induced release of noradrenaline in the prefrontal cortex of adult rats. Int. J. Neurosci., 37, 93-102 (1987).

37) Noback CR, Eisenman LM. Some effects of protein-calorie undernutrition on the developing central nervous system of the rat. Anat. Rec., 201, 67-73 (1981).

38) Patel AJ, Hayashi M, Hunt A. Selective persistent reduction in choline acetyltransferase activity in basal forebrain of the rat after thyroid deficiency during early life. Brain Res., 422, 182-185 (1987).

39) Díaz-Cintra S, Cintra L, Ortega A, Kemper T, Morgane PJ. Effects of protein deprivation on pyramidal cells of the visual cortex in rats of three age groups. J. Comp. Neurol., 292, 117-126 (1990).

40) Miñana-Solis MC, Angeles-Castellanos M, Buijs RM, Escobar C. Altered Fos immunoreactivity in the hypothalamus after glucose administration in pre- and post-weaning malnourished rats. Nutr. Neurosci., 13, 152-160 (2010).

41) Sato $S$, Nakagawasai O, Tan-No K, Niijima F, Suzuki T, Tadano T. Executive functions of postweaning protein malnutrition in mice. Biol. Pharm. Bull., 34, 1413-1417 (2011).

42) Nakagawasai O, Murata A, Arai Y, Ohba A, Wakui K, Mitazaki S, Niijima F, Tan-No K, Tadano T. Enhanced head-twitch response to 5-HT-related agonists in thiamine-deficient mice. J. Neural Transm., 114, 1003-1010 (2007).

43) Kameda SR, Fukushiro DF, Trombin TF, Procópio-Souza R, Patti CL, Hollais AW, Calzavara MB, Abílio VC, Ribeiro RA, Tufik S, D'Almeida V, Frussa-Filho R. Adolescent mice are more vulnerable than adults to single injection-induced behavioral sensitization to amphetamine. Pharmacol. Biochem. Behav., 98, 320-324 (2011).

44) Preece MA, Dalley JW, Theobald DE, Robbins TW, Reynolds GP. Region specific changes in forebrain 5-hydroxytryptamine ${ }_{1 \mathrm{~A}}$ and 5-hydroxytryptamine ${ }_{2 \mathrm{~A}}$ receptors in isolation-reared rats: an in vitro autoradiography study. Neuroscience, 123, 725-732 (2004). 
45) Lanier LP, Isaacson RL. Early developmental changes in the locomotor response to amphetamine and their relation to hippocampal function. Brain Res., 126, 567-575 (1977).

46) Altman J, Das GD. Autoradiographic and histological evidence of postnatal hippocampal neurogenesis in rats. J. Comp. Neurol., 124, 319-335 (1965).

47) Kaplan MS, Bell DH. Neuronal proliferation in the 9-month-old rodent-radioautographic study of granule cells in the hippocampus. Exp. Brain Res., 52, 1-5 (1983).

48) Kaplan MS, Bell DH. Mitotic neuroblasts in the 9-day-old and 11-month-old rodent hippocampus. J. Neurosci., 4, 1429-1441 (1984).

49) Kaplan MS, Hinds JW. Neurogenesis in the adult rat: electron microscopic analysis of light radioautographs. Science, 197, 10921094 (1977).

50) Coyle JT, Henry D. Catecholamines in fetal and newborn rat brain. J. Neurochem., 21, 61-67 (1973).

51) Sandeman DC, Benton JL, Beltz BS. An identified serotonergic neuron regulates adult neurogenesis in the crustacean brain. Dev. Neurobiol., 69, 530-545 (2009).

52) Lauder JM, Krebs H. Serotonin as a differentiation signal in early neurogenesis. Dev. Neurosci., 1, 15-30 (1978).

53) Lo Iacono L, Gross C. Alpha- $\mathrm{Ca}^{2+} /$ calmodulin-dependent protein kinase II contributes to the developmental programming of anxiety in serotonin receptor 1A knock-out mice. J. Neurosci., 28, 62506257 (2008).

54) Trulson ME, Jacobs BL. Behavioral evidence for the rapid release of CNS serotonin by PCA and fenfluramine. Eur. J. Pharmacol., 36, 149-154 (1976).

55) Adell A, Sarna GS, Hutson PH, Curzon G. An in vivo dialysis and behavioural study of the release of 5-HT by $p$-chloroamphetamine in reserpine-treated rats. Br. J. Pharmacol., 97, 206-212 (1989).

56) Gobbi M, Frittoli E, Uslenghi A, Mennini T. Evidence of an exocytotic-like release of $[3 \mathrm{H}] 5$-hydroxytryptamine induced by $d$-fenfluramine in rat hippocampal synaptosomes. Eur. J. Pharmacol., 238, 9-17 (1993).

57) Wolff M, Costet P, Gross C, Hen R, Segu L, Buhot MC. Age-dependent effects of serotonin-1A receptor gene deletion in spatial learning abilities in mice. Brain Res. Mol. Brain Res., 130, 39-48 (2004).

58) Kusserow H, Davies B, Hörtnagl H, Voigt I, Stroh T, Bert B, Deng DR, Fink H, Veh RW, Theuring F. Reduced anxiety-related behaviour in transgenic mice overexpressing serotonin 1A receptors Brain Res. Mol. Brain Res., 129, 104-116 (2004).

59) Carli M, Tatarczynska E, Cervo L, Samanin R. Stimulation of hippocampal 5-HT1A receptors causes amnesia and anxiolytic-like but not antidepressant-like effects in the rat. Eur. J. Pharmacol., 234, 215-221 (1993) 